February 2019

\title{
Shifting MNE taxation from national to global profits: A radical reform long overdue
}

\author{
Sara L. McGaughey \\ Department of Business Strategy and Innovation \\ Griffith University, Australia \\ Email: s.mcgaughey@griffith.edu.au \\ Pascalis Raimondos \\ School of Economics and Finance \\ QUT, Australia \\ Email: pascalis.raimondos@qut.edu.au
}

Sara McGaughey is Professor of International Business at Griffith Business School, Griffith University, and received her PhD from the University of Queensland. Her research is at the intersection of international strategy, organisation and entrepreneuership, and has appeared in Academy of Management Review, Journal of World Business, Journal of Management Studies, Management International Review and Business History, among others.

Pascalis Raimondos is Professor and Head of the School of Economics and Finance, QUT, Australia. He received his PhD from Essex University, and is a research fellow of CEPR and Cesifo. His main research fields are International Trade and Public Finance, including taxation of MNEs. His research has been published in The Economic Journal, Journal of International Economics, Journal of Public Economics and Journal of Development Economics, among others.

Acknowledgements: We greatly appreciate the helpful comments and guidance of Alain Verbeke (JIBS Editor-in-Chief), Gary Biddle (JIBS Area Editor) and an anonymous reviewer. The assistance of Griffith University librarians with some difficult to locate historical records is also gratefully acknowledged. 


\section{INTRODUCTION}

The agenda here has been set by a Point that Foss, Mudambi and Murtinu (2018) published in this journal. The authors address how to best tax the multinational enterprise (MNE) and argue in favour of substituting profit taxation with taxes on dividends and consumption.

Our Counterpoint argues that the Point operates within the realm of the current international tax system, where countries focus on the national profits of firms established within their borders. This system, called Separate Accounting, has passed its overdue date and is the true culprit of the many tax inefficiencies we currently observe. Moving to a zero tax on national profits and taxing instead dividends paid out to shareholders will induce MNEs to avoid paying dividends in countries where dividend taxes are high, and to pay dividends (if any) in countries where dividend taxes are low. A new dimension of income shifting and tax manipulation will be added in the 'to-do' list of global accounting firms. Instead, as our paper argues, a truly long-term solution must be based on the fact that these firms are global, and it is their global profit that needs to be taxed in a way that reflects the real economic presence of the firm within a county. That is, we advocate an alternate international tax system, namely Formula Apportionment, where countries tax an activity-based share of a firm's global profit. Interestingly, our advocacy is not new and builds on the foundations of a unitary taxation system with formula apportionment that was widely used before forces within the League of Nations moved from around 1933 to establish Separate Accounting as the international standard. Versions of unitary taxation have nonetheless continued to operate within federal countries around the world. From that experience, we now have empirical evidence that such a system does indeed reduce the sensitivity of the tax base to tax rate changes and thus reduces profit shifting and tax competition. The renewed popularity of Formula Apportionment as a system for taxing MNE profits is evident in the EU's current progress towards implementing it within EU's borders, and China's recent expression of 
interest in adopting it. Supporting all the above is the theoretical and empirical research that has taken place within international public finance over the past 40 years. ${ }^{1}$

Our Counterpoint will reflect on all the above and provide a narrative as to why a unitary taxation system with an activity-based apportionment of global MNE profits between countries is a credible candidate for an international corporate income tax reform. In building our narrative, we start by presenting the basic premise of Foss et al. (2018).

\section{THE BASIC PREMISE}

Foss et al. (2018) are right in arguing that the international corporate income tax system is broken. As they correctly point out, taxing a highly elastic tax base - viz. national profits will lead to tax evasion and will fail in raising revenues. Their conclusion that such a tax is inefficient is undeniably true and their proposal is logical: set the profit tax to zero and raise revenues from taxing dividends and consumption. ${ }^{2}$

In assessing the Foss et al. (2018) proposal, efficiency and as well as equity grounds should be considered. With respect to equity note that, in general, governments raise revenues to fund the production of public goods from two broad type of taxes: direct and indirect. We pay direct taxes on the income we earn and indirect taxes on the goods we buy. Such a combination of direct and indirect taxes rests on the principle that taxes should be paid both in terms of our ability (our income and wealth) and in terms of our actions (our consumption). The proposal in Foss et al. (2018) removes direct income taxes from corporations and puts emphasis on taxing the income individuals earn from dividends and their personal consumption. Clearly such a proposal will raise equity concerns. While

\footnotetext{
${ }^{1}$ An early survey of that literature can be found in Gresik (2001), while a more recent one is written by Keen and Konrad (2013).

${ }^{2}$ Removing corporate income taxation is also addressed in Gordon and Wilson (1989) and in Gordon (1992). More recently, a proposal of substituting profit taxation with cash-flow taxation has also gained momentum; see Auerbach, Devereux, Keen and Vella (2017a, 2017b).
} 
individuals will still be paying direct income taxes on their income, corporations will not. In this sense, the Foss et al. proposal 'accepts defeat' in taxing corporate income and proposes to reform the system so as to reduce efficiency losses.

However, we believe that other inefficiencies will arise. For example, a 'zero profit tax plus a dividend tax' will induce firms to not pay dividends and instead retain earnings, potentially funding less productive investments (see Chetty \& Saez, 2006). Moreover, a zero corporate tax will induce individuals to form companies and declare any income they get as corporate income (on which they will pay zero tax), and not as personal income. We will see a surge in company formation with the sole purpose of hosting personal income as corporate income. Such a reaction also has equity repercussions, as it is mostly the wealthy and resourceful individuals that will form company structures to avoid paying dividend taxes. On that basis, keeping the corporate income tax rate not so different from the personal income tax rate has long been a sensible tax policy advice (e.g. Gordon \& MacKie-Mason, 1994).

Despite the above concerns, the Foss et al. (2018) argument builds on a correct observation, viz. that national profits are highly mobile and thus not a good base to tax. Multinational firms have devised several ways to move profits to locations around the world where taxation rates and rules are 'firm-friendly'. Transfer prices - i.e. prices charged for intra-firm trade - have been historically the most popular method for profit shifting and several attempts have been made to regulate them. The OECD recommendation is that such prices should be set according to the arm's length principle (ALP), where trade within the firm should be charged the same price as trade between different firms (i.e. firms in arm's length) would be charged. While the principle is straightforward, its implementation is notoriously difficult when it comes to intellectual property rights and other intangible assets. Transfer pricing issues notwithstanding, global firms have developed other ways to shift profits where taxes are lowest (e.g. via financial engineering, such as thin capitalization, 
hybrid mismatch instruments, etc). Again the OECD has been at the forefront in trying to regulate their use (see the BEPS initiative by OECD). The reality remains, however, that it is relatively easy under the current international taxation system to shift national accounting profits (for some, 'paper money') to locations where taxes are low. With this context in place, we do agree with Foss et al. that taxing consumption is a much more efficient way of raising tax revenues than corporate income taxes. ${ }^{3}$

Overall, while we agree with Foss et al. (2018) that radical reform is needed, we argue in favour of a different reform of corporate income taxes - viz. unitary taxation with formula apportionment - and revisit its origins dating 100 years ago. As Jones and Khanna (2006) discuss, historical analyses can help us uncover the long-term effects of particular choices made, discern the contextual elements at play, and help point to alternate approaches or trajectories. We draw on these strengths of history and provide a rich (albeit somewhat brief) account of past events to better understand how the current international tax system came to be, and what shape a future reform of this system might take.

\section{INSIGHTS FROM HISTORY}

The origin of our current system for taxing MNEs dates back to the era immediately following World War I, when the International Chamber of Commerce (ICC) - newly formed in June 1920 to represent the interests of the business community - brought the issue of double taxation (i.e. over-taxation) to the doorstep of the equally young League of Nations. ${ }^{4}$ Post WW1 deliberations were infused with concerns of sovereignty, peace and the development of international trade; the conflicting interests of capital exporter nations and capital importers; and strong private sector interest and influence. Separate Accounting and

\footnotetext{
${ }^{3}$ The trend is clearly telling, with consumption taxes already being the largest source of tax revenues in many OECD countries; see OECD (2018a).

${ }^{4}$ Double taxation arises in international business when cross-border activity is taxable in more than one jurisdiction, and may thereby face a higher aggregate tax burden than purely domestic activity.
} 
Formula Apportionment were compared as solutions to the problems of the day. The ascendency of Separate Accounting was not a foregone conclusion, and reasons expressed in favour of a Formula Apportionment system back then are well aligned with many of the present-day challenges Foss et al. identify.

\section{Post-war 'Evils' of Taxation}

Before the First World War, double taxation was not of widespread concern for businesses. At the turn of the twentieth century, the most important tax revenue sources were tariffs, followed by taxes on land and real estate. Income taxes, where they existed, were mostly imposed upon property and wealth, and the size of the public sector and governments' 'tax take' was generally low compared to today (Rixen, 2008). The earliest recorded international tax agreement was concluded between France and Belgium in 1843 (League of Nations, 1925a) and related to the sharing of documents and information to assist the effective collection of taxes imposed by the laws of the two countries. Belgium was a "pioneer" in the area, with further tax administration cooperation agreements concluded with the Netherlands and Luxemburg in 1845 (Jogarajan, 2011: 687). France and Great Britain concluded a tax cooperation treaty in 1907 . The first known international treaty for the prevention of double taxation in relation to income tax was reached between the Austro-Hungarian Empire and Prussia in June $1899 .^{5}$ This was quickly followed in 1901 by a double taxation treaty with Liechtenstein, and with a number of other German states between 1903 and $1913{ }^{6}$ Swiss Cantons - as sovereign members of the Swiss Confederation with sovereign taxing rights fell under a confederal, constitutional prohibition of double taxation (League of Nations,

\footnotetext{
${ }^{5}$ Utilizing a then new concept in tax treaties, it allocated the right to tax business profits to the country where the permanent establishment (Betriesstätte) was located (Jogarajan, 2011).

${ }^{6}$ Not all agreed, with some members of the Prussian parliament apparently arguing that double taxation was not unfair. A similar view prevailed in England, where a double tax burden was seen as appropriate given the 'double benefit' of receiving public goods in two states (Rixen, 2008: 87).
} 
1928a; Langbein, 1986). Nonetheless, such treatments of double taxation were largely a regional phenomenon (Rixen, 2008).

This changed with the advent of World War I. The relative importance of new taxes on potentially mobile assets and activities such as personal or corporate income increased - in part to fund the war itself and then post-war reconstruction - making international double taxation more likely (Genschel \& Rixen, 2015). As explained by the League of Nations (1927: 8-9), the "evil" of double taxation had "become especially acute owing to the increase in the fiscal burdens consequent upon war." Double taxation was seen "to paralyse" international business activity and "to discourage initiative and thus constitutes a serious obstacle to the development of international relations and world production."

The Financial Committee of the League of Nations was entrusted with the study of double taxation, and decided in September 1921 to ask four economists - Bruins, Einaudi, Seligman and Stamp - to prepare a report on the matter. ${ }^{7}$ The terms of reference included a study of the economic consequences of double taxation; the possibility of formulating general principles as the basis for an international convention or amendment to the taxation system of individual countries; and of the extent to which conventions on double taxation should also establish an "international control" to prevent tax evasion (League of Nations, 1923: 2). That is, it recognised concerns of double taxation (i.e. over-taxation) and the potential for tax competition and profit shifting between nations (i.e. under-taxation).

The academic experts observed that the "ideal solution" to sovereign claims to tax the same corporate income "is that the individual's whole faculty should be taxed, but that it should be taxed only once, and that the liability should be divided among the tax districts according to... the doctrine of economic allegiance" (League of Nations, 1923: 20). The

\footnotetext{
${ }^{7}$ Prof. Bruins (Commercial University, Rotterdam), Prof. Senator Einaudi (Turin University), Prof. Seligman (Columbia University, New York) and Sir Josiah Stamp, K.B.E. (London University).
} 
"place of origin" - the place where the earnings are created - held the preponderant right to tax commercial establishments (League of Nations, 1923: 29-31 \& 39). ${ }^{8}$ Indeed, the allocation of taxing rights between multiple 'places of origin' was described "of special importance in all business taxation" (League of Nations, 1923: 30). Foreshadowing the fine slicing of global value chains that Foss et al. describe (see, also, Mudambi \& Puck, 2016; Verbeke \& Asmussen, 2016), the addendum specifically addressed the "allocation of earnings where the whole of the economic stages are not conducted within one area" and showed clear preference for activity-based taxation in recognising the potentially different locations and activities of value creation (League of Nations, 1923: 52-3). The Experts concluded by offering to look further into the matter if desired by the League - an offer that was then not taken up.

The Financial Committee of the League appointed a Committee of Technical Experts made up of tax administrators from Belgium, Czechoslovakia, France, Italy, the Netherlands, Switzerland and UK to study the more practical implications of double taxation and tax evasion, including a review of double taxation conventions then in force (League of Nations, 1925b). Their report led to an expanded Committee - to also included Argentina, Germany, Japan, Poland, USA and Venezuela. The April 1927 report of the expanded committee included a draft bilateral Convention for the Prevention of Double Taxation. It generally followed the recommendations of earlier reports, but also implied a preference for Separate Accounting in Article 5: "in the absence of accounts showing this income separately and in proper form, the competent administrations of the two Contracting States shall come to an arrangement as to the rules for its apportionment" (League of Nations, 1927: 11, emphasis added).

\footnotetext{
${ }^{8}$ This early work was concerned with issues much broader than only business profits, addressing the allocation of taxing rights of all sorts of income.
} 
The League's General Meeting of Government Experts on Double Taxation and Fiscal Evasion of 22 October 1928 was attended by representatives of over 27 countries. To mitigate conflict between the then capital exporting nations who favoured taxation at residence (e.g. Netherlands, U.K., U.S.A.) and capital importing nations (e.g. Italy, France, Germany) who preferred origin-based taxation, three alternative model bilateral conventions were developed rather than the single model (Genschel \& Rixen, 2015). National governments could draw on these non-binding model conventions as templates when developing binding, bilateral tax agreements. Article 5 (p. 8) removed explicit mention of separate accounts, recording that the "competent administrations of the two contracting states shall come to an arrangement as to the bases for apportionment [of income]." The commentary (League of Nations, 1928b: 12) noted that bases of apportionment will vary, giving preference through example to activitybased taxation.

The League Council also adopted the recommendation of the Technical Committee to appoint a Fiscal Committee on double taxation. The method for allocating business profits of an enterprise that had permanent establishments in both nations party to a bilateral convention had been left open by the various prior Committees and General Meeting. The "rules for the apportionment of profits or capital of undertakings operating in several countries" was thus identified as a topic for further study, along with an investigation of methods to prevent double taxation of income derived from patents and authors' rights (League of Nations, 1928b: 34-5).

\section{The Influence of International Business}

The League's deliberations were not divorced from business. The International Chamber of Commerce (ICC) - whose leadership included prominent businessmen from, for example, General Electric, Standard Oil Company and Deere and Company (Fahey, 1921) exerted influence throughout the League's work on double taxation and tax evasion. From its 
earliest interest in double taxation, the ICC had "maintained close contact with the League of Nations" (League of Nations, 1925a: 7-8, 1927), with "harmony existing between the [ICC and League] in pursuit of the same aim" (ICC submission to League of Nations, 1928c: 3). Commentators of the day noted that "suggestions of the Chamber for problems and courses of solution" in relation, for example, to the apportionment of corporate profits and double taxation "were frequently acted upon" (Wilk, 1940: 242). ICC delegates attended the meetings of the Committee of Experts on Double Taxation and Tax Evasion (League of Nations, 1927), used "personal contacts" as a "very frequent device of cooperation", and "leading personages of the Chamber" made delegations or were appointed to the League's Financial and other Committees (League of Nations, 1925a, 1929; Wilk, 1940: 232-3). With the ICC seen by some to represent "capitalist private traders," this fuelled perceptions of undue corporate influence over League deliberations. ${ }^{9}$

Consistent with the League's expert committees, the ICC emphasised that "the conclusion of bilateral agreements may be regarded as a step towards a more general agreement completely abolishing double taxation" (ICC submission, League of Nations 1928c: 3). The ICC was also vocal with regards to tax evasion. The various experts authoring the League of Nations' reports recognised that the question of tax evasion could only be solved if the relevant international agreements are adhered to by most countries and are made simultaneously. A functionally adequate response to tax evasion must be multilateral. If not, there would be capital flight to those countries not party to the multilateral agreement, and "the interests of the minority of States, which would alone have signed the conventions, might be seriously prejudiced" (League of Nations, 1925a: 34). Further, the League's Financial

\footnotetext{
${ }^{9}$ Kelly (2005, p. 261) described the acerbic response of one NGO in 1930 to the influence of the ICC over League activities, claiming that "organized public traders of the world" had "succeeded in entrenching themselves" in the authorities of the League "on a basis of equality of voice and voting with National governments", and wielded "such influence on behalf of their clients - the capitalist private traders - that they practically dominated the situation".
} 
Committee "strongly urged" consideration of the "disadvantage of placing any obstacles in the way of the international circulation of capital, which is one of the conditions of public prosperity and world economic reconstruction" post WW1 (League of Nations, 1925b: 1). Double taxation was seen to generate incentives for tax avoidance: "any excessive taxation, by its very burden, brings in its train tax evasion... The suppression of double taxation [is...] closely connected with the measures for the systemic prevention or checking of such evasion" (League of Nations, 1927: 9).

Perhaps not surprisingly, the International Chamber of Commerce was consistent in prioritising the "evils" of over-taxation and, "while in favour of carefully considered and equitable measures to prevent fiscal evasion", constrained its possibility:

"[The Congress of the ICC] Calls the attention of the League of Nations to the necessity of avoiding anything that might hamper the free play of competition and of economic laws, especially the free movement of capital and the freedom of the exchange market, or that might violate the secrecy of bankers' relations with their customers or of income-tax returns" (League of Nations, 1928c: 14).

Tax evasion continued to take a back seat in the League's deliberations. Moreover, the new Fiscal Committee included direct and ongoing representation from the International Chamber of Commerce to help secure the views of business enterprises (League of Nations, 1929).

\section{Triumph of Separate Accounting over Formula Apportionment}

The League's Fiscal Committee endorsed the ICC's and the prior experts' preference for a multilateral convention on double taxation once agreement, even on a limited scale, seemed possible. A questionnaire was sent to the Governments of "important commercial countries". A summary of replies by T.S. Adams - a professor at Yale University who had been a member of the expanded Technical Committee and advisor to the U.S. Treasury revealed "great diversity of law and practice" and a need for further "systematic and continuous study" (League of Nations, 1930: 10). The Fiscal Committee received a grant 
from the Rockefeller Foundation of \$90,000 (League of Nations, 1930), and devoted it to the question of apportionment and translation of the business taxation framework of the 1928 Conventions into an operable set of rules. The study was led by Dr Mitchell B. Carroll, who had for some years been connected with the work of the Government experts and Fiscal Committee as an assistant to Dr Adams. Initially covering France, Germany, Great Britain, Spain and the United States, the study was expanded to cover 27 nations and three American States. The Carroll Report - comprising five volumes, published between 1932 and 1933 was a turning point in the creation of the separate accounting 'standard' for the model conventions of international business taxation.

Carroll identified two primary methods of profit allocation for taxation: separate accounting and fractional (i.e. formula) apportionment. No country followed exclusively one method or the other (Carroll, 1933: 45). Fractional apportionment was the primary method for business taxation in Spain, in Swiss cantons, in Austria, Czechoslovakia and Hungary (under joint treaties) and in various States in the United States, and widely used elsewhere as a secondary method. In Spain, fractional apportionment had in law and practice replaced separate accounting for business enterprises from 1920, and was declared the only system that (i) assures enterprises are taxed according to their real capacity to pay and precludes overlapping assessments that result in taxation of more than 100 per cent; and (ii) permits the taxation of a subsidiary in accordance with their real importance in the enterprise as a whole. Dr Agustin Vinuales, who authored the Spanish report, was eloquent in asserting its virtues:

Taken as a whole, the Spanish system of apportioning profits [based on the principle of economic unity of the multi-establishment enterprise] deserves the honour in which it is held by business men in Spain. They cannot understand how anybody can be in doubt, at the present time, which is the better-a system so solidly constructed as the Spanish system, or a system so primitive as that of separate accounts, with which it must be admitted a priori that, although the operation of one undertaking may be completely controlled by another, yet the former is independent of the latter, or that the ideal of taxation is to make a 
concern running at a loss pay the tax on profits. The pious Spaniard has no longer a faith so profound (Carroll, 1932: 163).

While tax evasion had taken a back seat in the League's deliberations, in Spain the rejection of separate accounting was a Parliamentary response to public pressure following "scandalous frauds" and concerns over profit shifting. As explained by Dr Vinuales, "it was clear that, from the economic point of view, there could be no agent less autonomous than a subsidiary company. There have been so many cases of fraudulent evasion that public opinion in the country was unanimous on this point" (Carroll, 1932: 145).

Summarising his findings, Carroll (1933: 88) noted a "predilection for the method of separate accounting is evinced by the great majority of countries." Yet, in the same volume he observes:

In view of the ever-growing complexity of the structure of international enterprises and the apparent difficulties encountered by many in maintaining an accounting system which will reflect the true profits of each establishment, whether conducted as a branch or a subsidiary company, there is a tendency on the part of tax officials to resort more and more to fractional [i.e. formula] apportionment. (1933: 60)

Despite this observation, the Carroll report ultimately advocated a separate accounting, independent enterprise approach, and presented a draft multilateral convention that was sent for comment to Governments (League of Nations, 1935). The 1935 multilateral convention was never formally adopted, with most countries preferring bilateral agreements. Nonetheless, its provisions and language became part of the 1943 Mexico and 1946 London Model Conventions, which were forerunners to the modern UN and OECD Models. Although advisory only, provisions in the OECD and UN Models are typically closely followed in the bilateral tax conventions executed between nations, which currently number in excess of 3,600(!) (Chaisse, 2016). The Carroll Report is thus a major point in the 
development of international taxation as it essentially made the separate accounting and its arm's length principle a decisive concept in the taxation of MNEs.

The Carroll report has not been immune from criticism. Langbein (1986) and Langbein and Fuss (2018) offer substantive critiques. Among other criticisms, Carroll's repeated (and questionable) stress on the preference of administrators for separate accounting created the impression of international acceptance, while failing to acknowledge that it was almost always only a method of assessment, and not a legislative choice (Langbein, 1986). ${ }^{10}$ It was at the time unprecedented in the League's work to base model convention rules on administrative practices, rather than tax law. Carroll was, according to Langbein (1986: 6378), "a product of the [USA] Mellon Treasury" who conceived his role principally "to make the world safe from fractional apportionment" rather than one of "evaluating, in an unbiased way, alternative approach to the problem." Coincidentally, US companies had strong reason for keeping separate accounts, with the new United States Revenue Act of 1932 requiring that branch profits be separately determined when calculating both the tax due to foreign countries and credit for foreign taxes - a point made forcefully and early in the final volume of the Carroll report, which unreservedly began with a clear preference for Separate Accounting (Jones, 1933: 15).

Of course, the authors of the Carroll report were writing in a post war era of heightened US influence, and when there were less possibilities for profit shifting than today. There was less global capital mobility; less functional integration within groups; lower profits in affiliates; less importance of intangible property (although still recognised as vital); and less risk allocation (e.g. uncertain outcomes of R\&D). Nonetheless, the crucial point is that both formula apportionment based on global profits and separate entity accounting with arm's

\footnotetext{
${ }^{10}$ Where a statutory system did exist, it usually involved fractional apportionment (e.g. some USA states, Spain, Austria), decisional law (Swiss Cantons) or international tax treaties (e.g. among Austria, Hungary and Czechoslovakia).
} 
length pricing were seriously considered as potential remedies for double taxation and tax evasion related to cross border activity. Might formula apportionment now present a better solution to the current problems of both over and under taxation of MNEs?

\section{FORMULA APPORTIONMENT: THEORY AND EMPIRICS}

As briefly mentioned above, the central idea behind unitary taxation with formula apportionment is that a corporation consolidates the income of its global operations into a single measure of taxable (global) income. This income is then apportioned among countries according to a formula reflecting the corporate group's activity in each country. Activity has been traditionally measured by three variables: fixed assets, payroll, and sales. The countries can tax that portion of the global profit with the rate they want, thereby preserving national tax sovereignty.

The emphasis on consolidated global income renders profit shifting and all the mechanisms that make it possible (transfer prices, thin capitalization, etc.) unimportant; what is revenues/loans for one affiliate, is costs/debt for another and in calculating consolidated pre-tax profits they simply cancel out. This is indeed a great advantage. What instead becomes important is the formula that is used to apportion the global profit to a particular country for taxing purposes.

The representation of the Separate Accounting and Formula Apportionment taxation systems shown in Figure 1 is used to illustrate the core ideas behind the two systems.

\section{[Insert Figure 1 about here]}

In the Separate Accounting system each entity of the MNE reports to tax authorities its national profit. This (national) profit constitutes the tax base to which a country's statutory corporate income tax will be applied. How much is reported as national profit is something that the MNE decides and the resulting battery of instruments MNEs have for shifting 
reported national profits is ever growing. While the early focus was on the use of transfer prices - i.e. using internal trade prices to move revenues and costs to countries according to their taxes - internal loans and other financial instruments have also become important income-shifting instruments in recent years. ${ }^{11}$ Clearly, the incentive is to report low profits in high tax countries and high profits in low tax countries. While each country has the ability to audit MNEs' reported national taxes, these audits are imperfect as it is often difficult to prove (in law courts or otherwise) that MNEs have wrongly reported their national profits. MNEs spend billions of dollars on advice from the big 4 accounting and law firms to design and defend their tax strategies, and it is rare for them to hinge on illegal transactions. This notwithstanding, sensational media stories and their potential for reputational damage is something that MNEs like to avoid (e.g. LuxLeaks). As such, a reform of the international taxation system toward something more transparent and that reduces uncertainty and compliance costs is something that the international business community also seeks (International Chamber of Commerce, 2017).

The starting point in the Formula Apportionment system is the global profit the MNE creates. Any internal mechanism (transfer prices, loans, etc.) used to allocate a share of profit more or less to one country thus becomes irrelevant. Global profit is rather apportioned to each country on the basis of activities in each country. To understand how this could be calculated, consider the following example. An Australian company has its sole subsidiary in Hong Kong (country B in Figure 1). The headquarters entity in Australia (country A) employs 70 per cent of total fixed assets and carries 70 per cent of total payroll, but has only 40 per cent of total sales, with the remainder registered by the Hong-Kong entity. Assume an equal weight assigned to all three activities - fixed assets, payroll and sales. The MNE's global

\footnotetext{
${ }^{11}$ For example, Hechemeyer and Overesch (2017) report that $70 \%$ of all income shifting is due to mispricing practices while $30 \%$ is due to internal loans.
} 
income will be apportioned with $0.6[=(1 / 3)(0.7)+(1 / 3)(0.7)+(1 / 3)(0.4)]$ of taxed by the Australia and the remaining 0.4 taxed by the Hong-Kong.

From the above it is seen that an advantage of Formula Apportionment is that it focuses on global (consolidated) profits and it renders internal profit shifting activities unimportant. It is also an advantage that it uses real activity to apportion global profits among countries, which is not as mobile as accounting profits in the Separate Accounting taxation. However, any mobility of real activity (as little as that might be) is potentially also distortive. As McLure (1980) first argued and Gordon and Wilson (1986) proved, a formula that uses production inputs (e.g. capital, labour) as measurements of activity indirectly transforms the profit tax to an input tax, thus affecting where the MNE locates its inputs. Indeed, one can easily imagine firms relocating fixed assets and payroll into countries where taxation is low and infrastructure is attractive. While shifting tangible production inputs is not easy, firms may be incentivised to do exactly that if the tax they will pay depends on such activity. Thus, while Formula Apportionment is a solution to the profit shifting problems that we currently face, it may create other problems that potentially can be far more distortive. The overall conclusion is that Formula Apportionment is not a panacea and its implementation challenges should be carefully considered.

This is exactly what the public finance literature has been considering over the last 40 years. While the early literature documented problems of Formula Apportionment (Gordon \& Wilson, 1986), the more recent literature compares Separate Accounting and Formula Apportionment on efficiency grounds (see e.g. Riedel \& Runkel, 2007; Nielsen et al., 2010; Eichner \& Runkel, 2008, 2011; Runkel \& Schjelderup, 2011; Gresik, 2010, 2016; Liesegang, 2016). In that sense, the issue is not whether Formula Apportionment creates distortions or not, but whether the distortions that it creates are smaller or larger than the distortions Separate Accounting creates. This recent literature derives conditions under which Formula 
Apportionment dominates Separate Accounting. While these conditions are model-specific, they point to a series of fundamentals that are intuitive and worth highlighting here.

As Nielsen et al. (2010) show, the case for Formula Apportionment is stronger (1) the higher global profit is and (2) the easier it is for MNEs to shift national profits. Intuitively, while the latter exacerbates the tax revenue losses when using Separate Accounting, the former highlights the tax revenue gains countries experience when using Formula Apportionment. Eichner and Runkel (2008, 2011) and Runkel and Schjelderup (2011) go a further step and show that one can choose formula sharing rules so that Formula Apportionment always dominates Separate Accounting. Interestingly, a higher weight on sales emerges in this literature as a favored Formula Apportionment base. An intuitive reason for this is that while inputs are needed to produce sales, any explicit mention of inputs in the formula will make them a target for manipulation. ${ }^{12}$ Finally, as Riedel and Runkel (2007) have shown, the superiority of the Formula Apportionment system over Separate Accounting survives even if not all countries join the Formula Apportionment reform and thus remain outside the company tax reform area, i.e. at the 'water's edge'. Said another way, countries at the water's edge - for example, tax havens - cause more harm under Separate Accounting than under Formula Apportionment.

Overall, the theoretical public finance literature suggests that carefully designed Formula Apportionment taxation will reduce tax competition and the related inefficiencies. Of course, the question remains: Is there any evidence that corroborates these theoretical insights?

\footnotetext{
${ }^{12}$ Liesegang (2016) goes a step further and shows that sales at the origin (production) place better capture real economic activity than sales at destination (consumption) place.
} 
The USA has since mid-last century widely adopted a variant of a unitary taxation system among its member states. ${ }^{13}$ A firm operating within the USA computes its total US profit and apportions it to each state according to the activity that the firm has in that state. What enters the activity formula is a decision that the state makes unilaterally and noncooperatively. Each state can also have a different definition of what should enter the total US profit definition. As Anand and Sansing (2000) argued, such a lack of coordination on what is consolidated income and what enters the activity formula is bound to lead to high tax competition and thus inefficiencies. Using firm-level data from 1978 to 1994, Goolsbee and Maydew (2000) documented that the US unitary taxation system did incentivise US firms to shift employment towards states that had a low weight on payroll in the state activity formula. However, a recent study by Clausing (2016) extends the Goolsbee and Maydew (2000) analysis to 2012 and finds no effect of taxes on employment or on any other activity. Clausing (2016) argues that by including the recent period, one captures the decentralised harmonization that happened in terms of what is included in the definition of US total profit and what is included in the activity formula. Clausing (2016: 356-57) writes:

"In 1986, 80 percent of states that taxed corporate income used an equal-weighted formula, and 20 percent had higher weights on sales. By 2012, in contrast, only 17 percent of states that taxed corporate income used an equal-weighted formula; the rest had formulas with a larger weight on sales. Indeed, in recent years, many states have adopted single-sales formulas, where the entire weight is on the sales factor; by 2012, 14 states use this approach."

Clausing (2016) concludes that this improved design of Formula Apportionment is the main explanation as to why US firms do not to respond to changes in tax rates over a longer period of analysis.

\footnotetext{
${ }^{13}$ Historically, the use of apportionment in the US can be traced to 1842 when New Hampshire enacted a law that apportioned tax revenue to the state and localities according to the assessed value of railroad property. The Pennsylvania statute of 1868 expanded the apportionment method to the tax base of the entire firm, thereby expanding it from an intra- to an inter-state method. When Wisconsin adopted a state income tax in 1911, the law recognised multi-jurisdictional firms and provided for the apportionment of income based upon the value of sales, property and manufacturing costs within the state. See Foran and Gray (1988).
} 
Clausing's result for US echoes the experience in Canada; see Mintz and Smart (2004). Canada implemented in 1985 a co-ordinated Formula Apportionment system within its provinces with a common definition of what is total corporate income within Canada (i.e. a truly unitary taxation system) and what should be included in the activity sharing formula, viz. a 0.5 weight on payroll and a 0.5 weight on sales. The only thing that provinces can choose is the tax rate. Mintz and Smart (2004) show that firms that fall under this coordinated Formula Apportionment taxation system do not shift activities within Canadian provinces.

Such empirical evidence affirms the theoretical insight that a carefully designed unitary taxation together with an agreed and carefully designed formula sharing rule leads to less activity shifting and less tax competition. Indeed, when the EU initiated its corporate income tax reform in 2001, it was the Canadian implementation of unitary taxation they had in mind. We now turn to the EU experience in reforming its corporate income taxation system among its 28 member countries.

\section{THE EU CASE}

A primary objective of the European Commission is the creation of a competitive single internal market. The European Commission operates as a coordinating institution among the 28 member countries, and cannot impose its decisions without the unanimous approval of the European Council and the subsequent approval of each national parliament. While this sounds discouraging for reforms, the intense political will and system of delegation within the European Union (EU) has created a market that, according to Gutiérrez and Philippon (2018), is now more competitive than the USA. The Commission has always seen the reform of the corporate income taxation system within the EU as pivotal to that single competitive market.

A large free internal market with a tariff wall around it has been a perfect area for multinationals to establish and grow. With small sovereign countries like Ireland and 
Luxemburg offering attractive packages to MNEs, large EU countries have experienced negative effects from tax competition. Profit shifting and tax avoidance have become a source of competitive advantage for MNEs, with the Commission going so far as to argue that national tax authorities violate state aid law when they allow MNEs to pay less taxes (see the pending court case between the European Commission, the Irish tax authorities and Apple; European Commission, 2017).

In an attempt to change the rules of the game within the EU, the Commission submitted its first corporate income tax reform proposal in 2001, often called the "Ruding 2" report. The association to the original 1992 Ruding report was clear: while the 1992 report proposed (with failure) a common corporate tax rate among European countries, the "Ruding 2" report proposed a Common Consolidated Corporate Tax Base (CCCTB).

The initial CCCTB proposal was similar to the Canadian model described above, i.e. a unitary taxation system with an activity-based formula that apportions the consolidated income for taxation to the countries where MNEs locate. The formula mentioned in the CCCTB proposal included all three measures of activity - labour (both employment and payroll), fixed assets and sales at destination - each with equal weight. After 10 years of deliberations the Commission submitted in 2011 a proposal to the European Council for approval. Unfortunately, it was blocked by the small EU countries that did not want to see real activity being the basis of corporate taxation. Committed "to put the fight against corporate tax avoidance and unfair tax competition at the heart of its political agenda," the Commission reacknowledged CCCTB as a "holistic solution to profit shifting" and proposed in 2016 a step-wise introduction. The proposed intermediate first step was to agree on a Common Corporate Tax Base (CCTB), leaving the decision about how to apportion it for a later discussion (European Commission, 2016). This CCTB proposal was adopted in the ECON committee on 21 February 2018 and was discussed in plenary at the Parliament on 15 
March 2018. The enhanced proposal is now back in the hands of the Council (see European Parliament, 2018a). This latest proposal includes a couple of innovative provisions that should make the whole package attractive. First, it includes an Allowance for Investment Growth (AIG) provision, where the tax deduction of all R\&D expenses and of equity-funded investment (in line with debt-funded investments) is allowed. Second, it introduces for the first time ever a fourth activity variable within the allocation sharing formula that measures the 'data' activity that a MNE has within a country. Such a 'data factor' is in recognition that data presence (e.g. social media presence) has become an important part of the value creation that a particular subsidiary can bring to the table, and as such it should be recognised alongside labour, fixed assets and sales.

If implemented, it will be the first time ever that independent countries have agreed to coordinate (on a multilateral basis) the implementation of a more efficient system of corporate taxation beyond administrative or implementation issues. ${ }^{14}$ In that sense, it may become pivotal for the future of an international corporate income tax reform.

It is important to note that current interest in unitary taxation and formula apportionment is not limited to EU. It also attracting interest among emerging economies. Most notably, China has lately expressed an openness to the use of Formula Apportionment as a government sanctioned approach. In a submission to the United Nations, Tizhong and Wang (2013) - as Directors of the International Taxation and Anti-Avoidance Divisions of PRC's State Administration of Taxation - outlined the practical challenges that face developing countries when applying the arm's length principle to tax foreign MNEs, using the electronic manufacturing services sector as an example. Here the typical set up of operations

\footnotetext{
${ }^{14}$ Where multilateral agreements exist, they tend to be for administrative matters of international taxation e.g. the OECD Multilateral Convention on Administrative Assistance in Tax Matters, the EU Mutual Assistance Convention, and the Nordic Agreement. An early multilateral agreement for the avoidance of double taxation was made between Hungary, Italy, Poland, Romania and Yugoslavia in 1922, but was ratified by only Italy and Austria in 1926 (League of Nations 1928a: 73-5; United Nations, 1951: 14).
} 
involves group headquarters being located outside China, with the MNE's revenues underpinned by significant manufacturing contracts with third party global consumer electronics companies. The majority of the group's work force (including high-level operational staff) and tangible assets (e.g. factory plants) are located in China, but local profits are "stripped away" through the group's transfer pricing policies. Some of the practical challenges with transfer pricing include a lack of reliable public information on comparables; failure to fully recognise the developing country location advantages (e.g. low cost labour, production close to market) that contribute significant profits to the MNE group when determining the subsidiary's share of the profit; and poor recognition of the developing country subsidiary's contribution to intangibles through, for example, contract R\&D, improved manufacturing processes, or to further developing the market to monetize the value of the intangibles (Tizhong and Wang, 2013: 375-380). In such cases, China takes the view that "the assets and the people should largely dictate where the group's profits should stay, and a global formulary approach should be a realistic and appropriate option" (Tizhong \& Wang, 2013: 385, emphasis added).

Of course, there can be immense obstacles to the implementation of multilateral reforms of corporate income tax. Anticipating such obstacles, the enhanced 2016 CCCTB proposal by the European Commission has the important caveat that if not approved by the Council, it can nonetheless be implemented among a smaller set of countries within the EU. Again asserting this need to act swiftly, the European Parliament in March 2018 resolved that if it is not possible to achieve unanimous approval of CCCTB within a reasonable timeframe, as a last resort 'enhanced cooperation' should be adopted by Member States (Amendment 4, European Parliament 2018b). Enhanced cooperation is described in Article 329 of the Treaty on the Functioning of the European Union, and involves a minimum of nine EU countries coming together to establish advanced integration or cooperation in an area within EU 
structures. While all member states may participate in the deliberations, only those party to the enhanced cooperation may vote. Non-participating member states are not bound by the resulting legislation but are able to join the cooperation at any time. Enhanced cooperation is thus a means to move forward at least on a limited multilateral basis, with a view to broadening the cooperation over time.

Even more recently, on 15 January 2019 the European Commission proposed a phased move towards qualified majority voting (QMV) for certain areas of EU taxation policy. The current requirement for unanimity in tax matters was first adopted with the six member states in the $1950 \mathrm{~s}$, in contrast to the current 28 members. Unanimity has been described as increasingly "anachronistic, legally problematic and economically counterproductive" and used for sometimes spurious reasons (European Commission, 2019). This affects not only tax policy goals, but also progress in other policy goals - such as climate change or public health - where tax measures play an important supporting role. Under the proposal, qualified majority voting will be in place by 2025 for complex proposals such as an EU-wide CCCTB and a system for taxing the digital economy. ${ }^{15}$ Irrespective of these amendments to governance processes within the EU, the catalyst for the wider adoption of Formula Apportionment may well reside in the very nature and pervasiveness of digitalisation in the global economy.

\footnotetext{
${ }^{15}$ In accord with the EU Treaties and as is already the case in a number of other EU policy areas, the move to qualified majority voting would mean that tax proposals require the support of 55 per cent or more of EU states and at least 65 per cent of the EU population. See Consolidated Version of the Treaty on the Functioning of the European Union. Official Journal C 326, 26/10/2012 P. 0001 - 0390. Available at: https://eurlex.europa.eu/legal-content/EN/TXT/?uri=CELEX:12012E/TXT
} 


\section{THE DIGITAL ECONOMY: AN IMPETUS FOR MULTILATERAL TAX COOPERATION}

We suggest that digitalisation of economies is a powerful impetus for multilateral coordination in the taxation of MNEs. At the most basic level, digital technologies are transforming the compliance and investigatory work of tax authorities. Domestically, the introduction of a requirement to use software that records and secures sales data at the time of transaction has led to VAT revenues increasing by up to twenty per cent in some countries (OECD, 2018b). Information exchange between national tax authorities has also been enhanced through, for example, the Common Transmission System, which is a platform developed by the OECD for secure and automatic bilateral exchanges of financial account information between participating tax administrations.

More significantly, the digitalisation of the economy is exposing and exacerbating the inadequacies of the current Separate Accounting system of international taxation, pointing to the relative benefits (or lesser distortions) of Formula Apportionment. The underlying principle of corporate taxation is that profits should be taxed where value is created. Indeed, this 'value creation' paradigm parallels the doctrine of 'economic allegiance', whereby the locations at which value is created hold the preponderant rights to tax (League of Nations, 1923; Langbein \& Fuss, 2018). The digital economy amplifies deficiencies in the current system around where to tax (i.e. the allocation of rights to tax in a country) and how much to tax (i.e. the allocation of corporate income to a country).

First is the ability of MNEs to avoid tax by shifting mobile intangible assets to low tax jurisdictions. As Foss et al. describe in their Point, while intangibles are increasingly important to MNE value creation, they are notoriously difficult to value. Hence, MNEs can use intragroup payments (royalties) for which an objective transfer price is difficult to determine. Recent media scandals of Apple in Ireland are but one illustration. Indeed, in a 
recent study on structures used in aggressive tax planning, ${ }^{16}$ three of the seven model structures involved the use of intellectual property (Ramboll Management Consulting \& Corit Advisory, 2015).

Second is a heightened potential for misalignment between value creation and tax allocations for globally active firms who do not require a physical presence. Double taxation treaties are most often negotiated on the basis of the OECD Model Double Tax Convention, whereby having a permanent establishment requires, among other things, a fixed place of business. The presence of a permanent establishment grants taxing rights to the host country. Yet businesses can increasingly supply both physical or digital products (e.g. Amazon's books or Apple's iTunes) and services (e.g. PayPal payments or Netflix streaming) to consumers around the world, or act as online marketplaces (e.g. eBay) and intermediary service providers (Booking.com, or Airbnb and Uber in the share economy) without any physical presence (Spinosa \& Chand, 2018). The international footprint of digital MNEs ${ }^{17}$ is thus characterised by far fewer assets in the location of their foreign sales compared to traditional international businesses, thereby creating 'scale without mass' (Dourado, 2015; UNCTAD, 2017). Some MNEs are able to choose at will the location of core functions and value drivers, leading to calls for, and considerable debate over, a meaningful definition (criteria and measures) of a taxable 'digital presence'.

Third and related are user contributions to value creation in the allocation of taxable profits across national jurisdictions that are not well catered. Instead of the one-to-one buyerseller exchanges traditionally studied in the IB field, exchanges may involve one-to-many or

\footnotetext{
${ }^{16}$ Following an EU recommendation, Ramboll \& Corit (2015, p. 15-16) define aggressive tax planning as: "taking advantage of the technicalities of a tax system or of mismatches between two or more tax systems for the purpose of reducing tax liability. Aggressive tax planning can take a multitude of forms. Its consequences include double deductions (e.g. the same loss is deducted both in the state of source and residence) and double non-taxation (e.g. income which is not taxed in the source state is exempt in the state of residence)."

${ }^{17}$ Digital MNEs include firms that operate entirely in a digital environment (e.g. internet platforms and providers of digital solutions) and firms that combine a significant digital dimension with a physical one (e.g. e-commerce and digital contents) (UNCTAD, 2017: 165).
} 
many-to-many parties through digital platforms (Coviello, Kano \& Liesch, 2017). While access to social network service, internet communication and content sharing mechanisms may be 'free' to the user, users passively contribute to value creation through searches, interactions and other activities that reveal preferences and interests. This information becomes valuable data for the digital business. Access to the users worldwide can be sold to other firms for advertising purposes, along with data sets and algorithms used to personalise content and target potential customers (e.g. Google). Additionally, a large part of the value derived by users of an online platform is created by other users who actively contribute content (e.g. Facebook, YouTube). This content can be central to attracting additional users, building trust and reputation (e.g. through reviews), and enhancing brand value - thereby further growing the network of users and generating network effects. Thus, the end-user both consumes and (passively or actively) co-produces, creating value as a 'prosumer'. ${ }^{18}$

There is, however, currently no international consensus on the extent to which user participation in, or across, foreign jurisdictions constitutes value creation activities for which taxable profits should be attributed to the digitalised business (OECD, 2018b). While this challenge exists for both Separate Accounting and Formula Apportionment, user contributions will be more manipulable by digital MNEs under Separate Accounting. Notably, two thirds of the large digital MNEs have their headquarters in the US, compared to only $20 \%$ for other MNEs, and their importance in the global economy is rapidly growing (UNCTAD, 2017). Corporate interest will inevitably play a role in shaping our international tax system now, just as it did 100 years ago. It is governments who will seek Formula Apportionment.

\footnotetext{
${ }^{18}$ The term 'prosumer' was first coined by futurist Alvin Toffler (1970) in his book Future Shock.
} 
With delays in achieving consensus and coordinated action, an increasing number of countries are implementing unilateral measures in response to the taxation challenges raised by the digital economy, or proposing interim measures. ${ }^{19}$ However, the introduction of country-specific tax regimes and interim measures can create distortions to competition, may increase the risk of double taxation and potentially violate bilateral treaties, and increases uncertainty, complexity and compliance costs for businesses operating across borders. Such fears have further "increased the sense of urgency that common policy options need to be developed" (see European Commission, 2018; ICC, 2018; OECD 2018b, p. 159). The most recent tax policy note of the $\operatorname{OECD}(2019: 2)$ recognises that reform "may reach into fundamental aspects of the current international tax architecture." While it remains within the Separate Accounting paradigm, many of the proposals challenge generally accepted corner stones of the current rules, pointing to a stupefying complexity of amendments. With separate accounting ill-equipped to meet the challenges posed by the rapid digitalisation of the global economy, digitalisation presents a powerful opportunity to interest wider groupings of countries in multilateral tax coordination using Formula Apportionment.

\section{CONCLUDING REMARKS}

For almost a century we have had a system for taxing global firms that has encouraged tax competition and profit shifting. Reducing tax avoidance and profit shifting should be a primary objective in any redesign of the system. In addition, double taxation and concerns over tax sovereignty must also be at the fore. Reconciling all three - tax competition, double taxation and tax sovereignty - is, indeed, not an easy task.

\footnotetext{
${ }^{19}$ Examples include the UK Digital Services Tax announced in 2018 for effect in April 2020; India's Equalisation Levey of 2016; Italy's Levy of Digital Transactions adopted in 2017 and effective from 2019, to name a few. See OECD (2018b) and Valente (2018).
} 
The Point made by Foss et al. (2018) starts from this same initial premise, namely that the international taxation system is broken, but radically proposes to totally remove profit taxation and only tax dividends paid out to individuals, as well as their personal consumption. We argue that taxing dividends will create new distortions, as there will be incentives to not pay dividends or to report personal income as corporate income. We further argue that even if dividends are paid out, individuals will prefer to receive dividends in countries will low dividend taxation - and a new cross-country income shifting opportunity will loom.

Our proposal is to turn our focus to an alternative international system of taxation that will help address both tax competition and double taxation, while keeping tax sovereignty unchallenged. It is a 'back to the future' proposal, with an historical lens reminding us that our proposal is not 'new'. Rather, it builds on a system that was used before World War I by sovereign nations and within federations to supress both tax competition and double taxation of MNEs. In short, we propose a unitary tax system with a carefully designed formula apportionment.

Systems for taxing MNEs are not devised in a vacuum, and consideration of economic factors and political motivations are always relevant. The historical records reveal the key role played by certain countries and interests in shaping our current system of international taxation at a pivotal moment in time, post World War I. With an accumulation of theoretical and empirical evidence regarding Formula Apportionment, tangible progress towards its implementation in the EU, growing interest from China as an emerging economic power, and pervasive digitalisation in the world economy, taxing an activity-based share of a firm's global profit is long overdue. 


\section{REFERENCES}

Auerbach, A.J., Devereux, M.P., Keen, M. \& Vella, J. 2017a. Destination-based cash flow taxation. Saïd Business School WP 17/01.

Auerbach, A.J., Devereux, M.P., Keen, M. \& Vella, J. 2017b. International tax planning under the destination-based cash flow tax. National Tax Journal 70 (4), 783-802.

Anand, B. \& Sansing, R. 2000. The weighting game: formula apportionment as an instrument of public policy. National Tax Journal 53(2): 183-99.

Carroll, M.B. 1932. Taxation of Foreign and National Enterprises: Studies of the tax systems and the methods of allocation of the profits of multinational enterprises operating in more than one country General survey of the allocation methods employed in France, Germany, Spain, the United Kingdom and the United States of America. Vol.1. Study conducted by a subcommittee of the Fiscal Committee, under the direction of M.B. Carroll, League of Nations, Geneva. Document no: C.73.M.38.1932.II.A

Carroll, M.B. 1933. Taxation of foreign and national enterprises: Methods of allocating taxable income, Vol.4. Study conducted by a subcommittee of the Fiscal Committee, under the direction of M.B. Carroll, League of Nations, Geneva. Document no:

C.425(b).N.217(b).1933.II.A

Chaisse J. 2016. International investment law and taxation: from co-existence to cooperation. E15 Task Force on Investment Policy, Strengthening the Global Trade and Investment System for Sustainable Development, International Centre for Trade and Sustainable Development (ICTSD) and World Economic Forum, Geneva, Switzerland.

Chetty, R. \& Saez, E. 2006. The effects of the 2003 dividend tax cut on corporate behavior: interpreting the evidence. American Economic Review 96(2): 124-129.

Clausing, K.A. 2016. The U.S. state experience under formulary apportionment: are there lessons for international reform? National Tax Journal, 69(2): 353-386.

Coviello, N., Kano, L. \& Liesch, P.W. 2017. Adapting the Uppsala model to the modern world: Macro-context and microfoundations. Journal of International Business Studies, 48: 1151-1164.

Dourado, A.P. 2018. Digital taxation opens the pandora box: The OECD interim report and the European Commission proposals. Intertax, 46(6-7): 565-572.

Eichner, T. \& Runkel, M. 2008. Why the European Union should adopt formula apportionment with a sales factor. Scandinavian Journal of Economics 110(3): 567-589.

Eichner, T. \& Runkel, M. 2011. Corporate income taxation of multinationals in a general equilibrium market. Journal of Public Economics 95(7/8): 723-733.

European Commission. 2016. Common Consolidated Corporate Tax Base. https://ec.europa.eu/taxation_customs/business/company-tax/common-consolidatedcorporate-tax-base-ccctb en. Accessed 5 September 2018.

European Commission. 2017. State aid: Commission refers Ireland to Court for failure to recover illegal tax benefits from Apple worth up to $€ 13$ billion. Press release, 4 October. http://europa.eu/rapid/press-release_IP-17-3702_en.htm. Accessed 5 September 2018.

European Commission. 2018. Commission staff working document impact assessment. Accompanying the document Proposal for a Council Directive laying down rules relating to the corporate taxation of a significant digital presence and Proposal for a Council 
Directive on the common system of a digital services tax on revenues resulting from the provision of certain digital services. 21 March. SWD(2018) 81 final/2.

European Commission. 2019. Commission launches debate on a gradual transition to more efficient and democratic decision-making in EU tax policy. Press Release, 15 January. http://europa.eu/rapid/press-release_IP-19-225 en.htm?es_p=8378983. Accessed 18 January 2019.

European Parliament. 2018a. Briefing on EU legislation in progress: CCCTB, 14 June. http://www.europarl.europa.eu/RegData/etudes/BRIE/2017/599395/EPRS_BRI(2017)5993 95_EN.pdf. Accessed 5 September 2018.

European Parliament, 2018b. P8_TA(2018)0087: European Parliament legislative resolution of 15 March 2018 on the proposal for a Council directive on a Common Consolidated Corporate Tax Base (CCCTB), (COM(2016)0683 - C8-0471/2016 - 2016/0336(CNS)). Accessed 21 January 2019.

Fahey, J. H. 1921. The international chamber of commerce. The Annals of the American Academy of Political and Social Science, 94(1): 126-130.

Foran, N. \& Gray, D. 1988. The evolution of the unitary tax apportionment method. The Accounting Historians Journal, 15(1): 65-87.

Foss, N.J., Mudambi, R. \& Murtinu, S. 2018. Taxing the multinational enterprise: On the forced redesign of global value chains and other inefficiencies. Journal of International Business Studies. doi.org/10.1057/s41267-018-0159-3

Genschel, P. \& Rixen, T. 2015. Settling and unsettling the transnational legal order of international taxation. In T. Halliday \& G. Shaffer (Eds), Transnational legal orders: 154186. New York: Cambridge University Press.

Goolsbee, A. \& Maydew, E. L. 2000. Coveting thy neighbor's manufacturing: The dilemma of state income apportionment. Journal of Public Economics, 75(1): 125-143.

Gordon, R.H. 1992. Can capital income taxes survive in open economies? Journal of Finance, 47(3): 1159-1180.

Gordon, R.H. \& Wilson, J.D. 1986. An examination of multijurisdictional corporate income taxation under formula apportionment. Econometrica, 54(6): 1357-1373.

Gordon, R.H. \& Wilson, J.D. 1989. Measuring the efficiency cost of taxing risky capital income. American Economic Review, 79(3), 427-439.

Gordon, R.H. \& MacKie-Mason, J. 1994. Tax distortions to the choice of organizational form. Journal of Public Economics, 55(2): 279-306.

Gresik, T. 2001. The taxing task of taxing transnationals. Journal of Economic Literature, 39(3): 800-838.

Gresik, T. 2010. Separate accounting vs. formula apportionment: A private information perspective. European Economic Review, 54(1): 133-149.

Gresik, T. 2016. Allowing firms to choose between separate accounting and formula apportionment taxation. Journal of Public Economics 138, 32-42.

Gutiérrez, G. \& Philippon, T. 2018. How EU markets became more competitive than US markets: a study of institutional drift. NBER Working Paper No. 24700. 
Heckemeyer, J. \& Overesch, M. 2017. Multinationals' profit response to tax differentials: effect size and shifting channels. Canadian Journal of Economics 50, 965-994.

International Chamber of Commerce (ICC). 2017. ICC comments on the OECD request for input on work regarding the tax challenges of the digitalised economy. https://iccwbo.org/publication/icc-comments-oecd-request-input-work-regarding-taxchallenges-digitalised-economy/. Accessed 29 January 2019.

International Chamber of Commerce (ICC). 2018. 3 ways digitalisation is shaping the future of taxation. 3 July. https://iccwbo.org/media-wall/news-speeches/3-ways-digitalisationshaping-future-taxation/

Jogarajan, S. 2011. Prelude to the international tax treaty network: 1815-1914 early tax treaties and the conditions for action. Oxford Journal for Legal Studies, 31(4): 679-707.

Jones, R.C. 1933. Taxation of foreign and national enterprises: Allocation accounting for the taxable income of industrial enterprises, Vol.5. League of Nations, Geneva. Document no. C.425(c).M.217(c).1933.II.A

Jones, G. \& Khanna, T. 2006. Bringing history (back) into international business. Journal of International Business Studies, 37(4): 453-468.

Keen, M. \& Konrad, KA. 2013. The theory of international tax competition and coordination, in A.J. Auerbach, R. Chetty, M. Feldstein \& E. Saez (Eds), Handbook of public economics, vol. 5: 257-328. Amsterdam: North-Holland.

Kelly, D. 2005. The International Chamber of Commerce, New Political Economy, 10(2): 259-271.

Langbein, S.I. 1986. The unitary method and the myth of arm's length. Tax Notes, 30(8 February): 625-81.

Langbein, S.I. \& Fuss, M.R. 2018. The OECD/G20-BEPS-project and the value creation paradigm: Economic reality disemboguing into the interpretation of the 'arm's length' standard. The International Lawyer, 51(2): 259-409.

League of Nations. 1923. Report on double taxation. Submitted to the Financial Committee by Professors Bruins, Einaudi, Seligman and Sir Josiah Stamp, Geneva: League of Nations, Document E.F.S.73.F.19; April 5.

League of Nations. 1925a. Double taxation and Tax Evasion. Report and Resolutions submitted by the Technical Experts to the Financial Committee of the League of Nations, Geneva: League of Nations, Document F. 212; February.

League of Nations. 1925b. Double Taxation and tax evasion. Extract of the Report of the Financial Committee to the Council of the League of Nations, Geneva: League of Nations, June $8^{\text {th }}$.

League of Nations. 1927. Double taxation and tax evasion. Report presented by the Committee of Technical Experts on Double Taxation and Tax Evasion, Geneva: League of Nations, C. 216. M 85. 1927 II.

League of Nations. 1928a. Double taxation and fiscal evasion. Collection of international agreements and internal legal provisions for the prevention of double taxation and fiscal evasion. Document C.345.M.102.1928.II. $1^{\text {st }}$ October, Geneva. 
League of Nations. 1928b. Double taxation and tax evasion. Report presented by the General Meeting of Government Experts on Double Taxation and Tax Evasion, $1^{\text {st }}$ October Geneva. Document C.562.M.178.1928.II.

League of Nations. 1928c. Double taxation and fiscal evasion. General Meeting of Government Experts, October 1928. Document C.495.M.147.1928.II; Geneva, $19^{\text {th }}$ September.

League of Nations. 1929. Fiscal Committee: Report to the Council on the Work of the First Session of the Committee, Geneva. Document C516.M.175.1929.II.

League of Nations. 1930. Fiscal Committee: Report to the Council on the Work of the First Session of the Committee, Geneva. Document C.340.M.140.1930.II

League of Nations. 1935. Fiscal Committee: Report to the Council on the Fifth Session of the Committee, 12-17 June, Geneva. Document C.252.M.124.1935.II.A.

Liesegang, C. 2016. Measuring sales in the apportionment formula: origin vs. destination principle. Unpublished Ph.D. Dissertation, TU Berlin. https://depositonce.tuberlin.de/bitstream/11303/6508/3/liesegang_caterina.pdf. Accessed 5 September 2018.

McLure, C.E. 1980. The state corporate income tax: lambs in wolves' clothing. In A.J. Aaron \& M.J. Boskin, (Eds), The economics of taxation: 327-336. Washington DC: The Brookings Institution.

Mintz, J. \& Smart, M. 2004. Income shifting, investment, and tax competition: theory and evidence from provincial taxation in Canada. Journal of Public Economics 88(6): 11491168.

Mudambi, R. \& Puck, J. 2016. A global value chain analysis of the 'regional strategy' perspective. Journal of Management Studies, 53(6): 1076-1093.

Nielsen, S.B., Raimondos-Møller, P. \& Schjelderup, G. 2010. Company taxation and tax spillovers: separate accounting versus formula apportionment. European Economic Review 54(1): 121-132.

OECD. 2018a. Consumption tax trends 2018: VAT/GST and excise rates, trends and policy issues, OECD Publishing, Paris. https://doi.org/10.1787/ctt-2018-en. Accessed 18 January 2019.

OECD. 2018b. Tax challenges arising from digitalisation - Interim report 2018: Inclusive framework on BEPS. OECD/ G20 Base Erosion and Profit Shifting Project, OECD Publishing, Paris. http://dx.doi.org/10.1787/9789264293083-en. Accessed 18 January 2019.

OECD. 2019. Addressing the tax challenges of the digitalisation of the economy-Policy note. As approved by the Inclusive Framework on BEPS on 23 January 2019. OECD/ G20 Base Erosion and Profit Shifting Project. http://www.oecd.org/tax/beps/policy-note-bepsinclusive-framework-addressing-tax-challenges-digitalisation.pdf. Accessed 30 January 2019.

Ramboll Management Consulting \& Corit Advisory. 2015. Study on structures of aggressive tax planning and Indicators, Taxation Papers, No 61, DG Taxation and Customs Union, European Commission.

Riedel, N. \& Runkel, M. 2007. Company tax reform with a water's edge. Journal of Public Economics, 91(7/8): 1533-54. 
Rixen, T. 2008. The political economy of international tax governance. Transformations of the State series. Hampshire and New York: Palgrave Macmillan.

Runkel, M. \& Schjelderup, G. 2011. The choice of apportionment factors under formula apportionment. International Economic Review, 52(3): 913-934.

Spinosa, L. \& Chand, V. 2018. A long-term solution for taxing digitalized business models: Should the permanent establishment definition be modified to resolve the issue or should the focus be on a shared taxing rights mechanism? Intertax, 64(6-7): 476-494.

Tizhong, L. \& Wang, X. 2013. 'China country practices'. In United Nations practical manual on transfer pricing for developing countries: 374-387. New York: United Nations.

Toffler, A. 1970. Future shock. New York: Bantam Books.

UNCTAD, 2017. World investment report 2017: Investment and the digital economy. United National Conference on Trade and Development, Geneva.

United Nations. 1951. International tax agreements. Vol. III, World guide to international tax agreements 1843-1951, New York.

Valente, P. 2018. Digital revolution. Tax revolution? Special Reports, Tax Notes International, 72(4a): 117-126.

Verbeke, A. \& Asmussen, C.G. 2016. Global, local or regional? The locus of MNE strategies. Journal of Management Studies, 53(6): 1051-1075.

Wilk, K. 1940. International organization and the international chamber of commerce. Political Science Quarterly, 55(2): 231-46. 
Figure 1. Contrasting Separate Accounting and Formula Apportionment

Separate Accounting

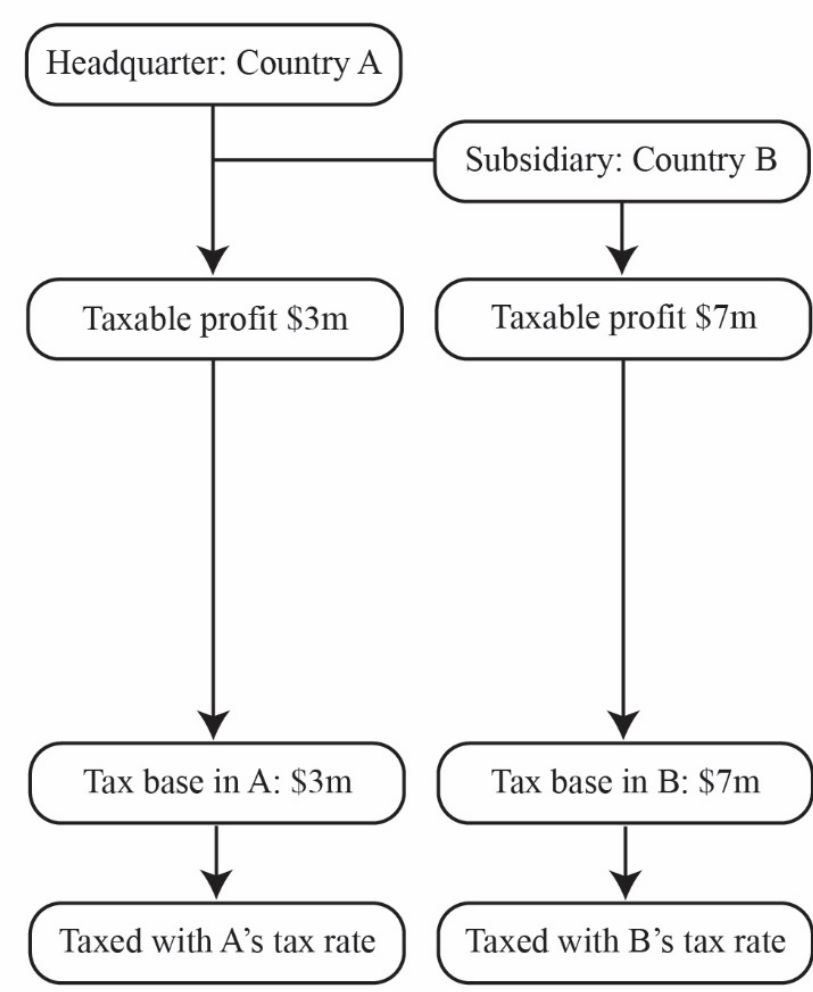

Formula Apportionment

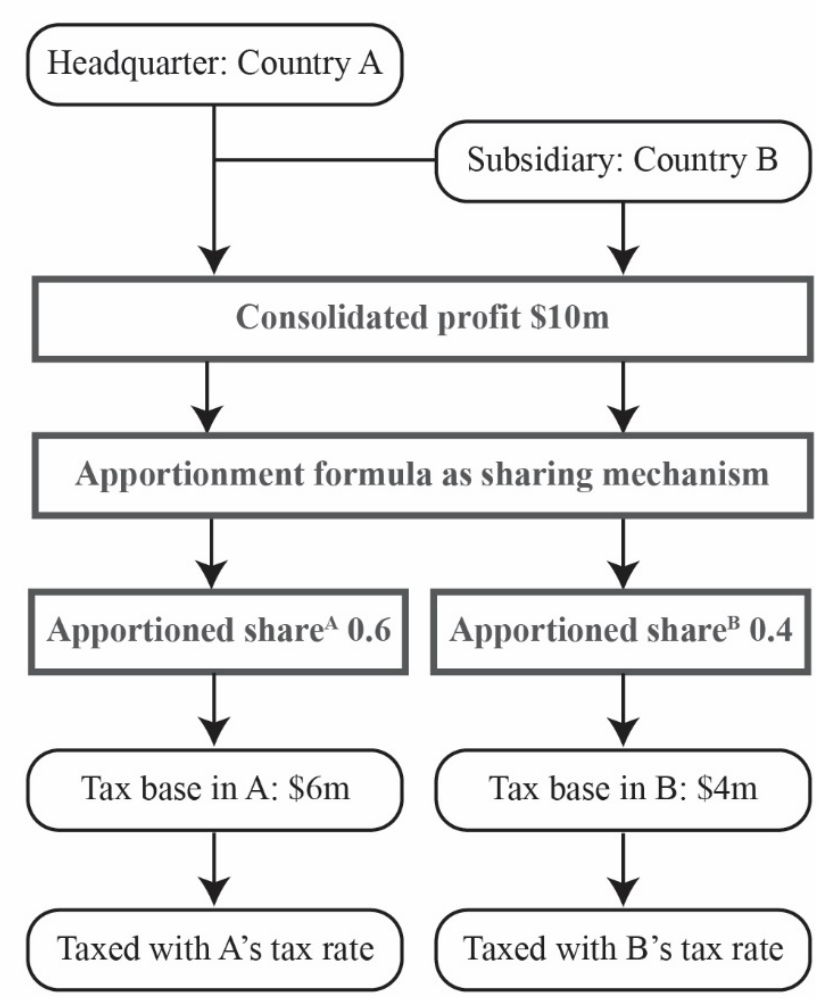

Adapted from Liesegang (2016) 